\title{
Pengaruh Gaya Kepemimpinan, Pendidikan dan Pelatihan, dan Lingkungan Kerja terhadap Kinerja Anggota Satuan Polisi Pamong Praja di Kabupaten Kotawaringin Timur
}

\author{
Arson $^{1,2 *}$, Bambang Mantikei ${ }^{3}$, Usup Riassy Christa ${ }^{3}$ \\ ${ }^{1}$ Satuan Polisi Pamong Praja Kabupaten Kotawaringin Timur \\ ${ }^{2}$ Alumni Program Studi Magister Manajemen Universitas Palangka Raya \\ ${ }^{3}$ Program Studi Magister Manajemen Universitas Palangka Raya \\ * Korespondensi: Arson (Email: arsonspt08@gmail.com)
}

\begin{abstract}
The purpose of this study were to analyze the influence of leadership style, education and training, and working environment on performance of civil service police member (Satuan Polisi Pamong Praja/Satpol PP) in Kotawaringin Timur regency. A descriptive quantitative analysis was used to examine 88 personnel of the unit. The results indicate that, first, leadership style has no definite and significant effect on personnel' performance. Secondly, education and training have a significant effect on members' performance. Lastly, a pleasant working environment has positively affected the personals' performance. This research suggests strengthening a positive leadership model that can make the work atmosphere more comfortable, increasing employees' engaged and enthusiastic so that they are willing to put their potency in order to complete the task.
\end{abstract}

Keywords

Leadership style, education and training, working environment, actual performance, civil service police

\section{PENDAHULUAN}

Untuk melaksanakan ketentuan Pasal 256 ayat (7) Undang-Undang Nomor 23 Tahun 2014 tentang Pemerintahan Daerah, pada 3 Mei 2018, Presiden Joko Widodo telah menandatangani Peraturan Pemerintah (PP) Nomor 16 Tahun 2018 tentang Satuan Polisi Pamong. Dalam PP ini disebutkan, untuk menegakkan Peraturan Daerah (Perda) dan Peraturan Kepala Daerah (Perkada), menyelenggarakan ketertiban umum dan ketenteraman, serta menyelenggarakan perlindungan masyarakat, di setiap provinsi dan kabupaten kota dibentuk Satuan Polisi Pamong Praja yang disebut Satpol PP. Pembentukan Satpol PP ditetapkan dengan Perda provinsi dan Perda kabupaten/kota sesuai dengan ketentuan peraturan perundang-undangan.

Menurut Peraturan Pemerintah tersebut, Satpol PP provinsi dalam melaksanakan tugasnya bertanggung jawab kepada gubernur melalui sekretaris daerah provinsi. Satpol PP kabupaten/kota bertanggung jawab kepada bupati/wali kota melalui sekretaris daerah kabupaten/kota.
Menurut PP ini, Satpol PP berwenang: a) melakukan tindakan penertiban nonyudisial terhadap warga masyarakat, aparatur, atau badan hukum yang melakukan pelanggaran atas Peraturan Daerah dan/atau Peraturan Kepala Daerah; b) menindak warga masyarakat, aparatur, atau badan hukum yang mengganggu ketertiban umum dan ketenteraman masyarakat; c) melakukan tindakan penyelidikan terhadap masyarakat, aparatur, atau badan hukum yang diduga melakukan pelanggaran atas Perda dan/atau Perkada; dan d) melakukan tindakan administratif terhadap warga masyarakat, aparatur, atau badan hukum yang melakukan pelanggaran Perda dan/ atau Perkada.

Satpol PP dalam melaksanakan penegakan Perda bertindak selaku koordinator Penyidik Pegawai Negeri Sipil (PPNS) di lingkungan Pemerintah Daerah, dapat berkoordinasi dengan TNI, Polri, Kejaksaan, dan pengadilan yang berada di daerah provinsi/kabupaten/ kota. PP ini juga menegaskan, penyelenggaraan penegakan Perda dan Perkada oleh Satpol PP dilaksanakan sesuai dengan standar operasional prosedur dan kode etik. 
Program pendidikan dan pelatihan dibutuhkan bagi anggota Satpol PP yang mengarahkan anggota kepada sikap profesionalisme. Prinsip pendidikan dan pelatihan harus jelas sehingga arah atau tujuan yang dicapai juga jelas. Dengan melihat kewenangan yang diberikan kepada Satpol PP yang memiliki keterampilan, pengetahuan, keahlian dan kemampuan untuk menghadapi berbagai masalah dan tantangan yang seringkali muncul disetiap operasi penertiban di lapangan. Saat ini Satpol PP di Kabupaten Kotawaringin Timur juga tengah dihadapkan pada persoalan lingkungan kerja, misalnya kurang memadai saran dan prasaran yang ada, sedangkan dilain pihak kondisi lingkungan kerja yang baik akan memberikan kenyamanan anggota dalam rangka meningkatkan kinerja anggota Satpol PP sehingga dapat mengerjakan tugas-tugas dengan baik. Dalam upaya meningkatkan kinerja, maka segala persoalan dalam lingkungan kerja penting menjadi bahan evaluasi dan menjadi perhatian dalam rangka menumbuhkan motivasi kerja dalam pelaksanaan tugas masing-masing. Dengan demikian faktor diklat, faktor lingkungan kerja dan faktor gaya kepemimpinan pada Satpol PP sangat diperlukan dalam rangka meningkatkan kinerja anggota Satpol PP dan merupakan masalah penting dalam institusi yang umum nya dipergunakan untuk menggambarkan kinerja organisasi secara keseluruhan.

Berdasarkan uraian tersebut diperlukan suatu kajian pengaruh gaya kepemimpinan, pendidikan dan pelatihan, lingkungan kerja terhadap kinerja anggota satuan polisi pamong praja di SOPD Satuan Polisi Pamong Praja Kabupaten Kotawaringin Timur.

\section{METODOLOGI}

\subsection{Ruang Lingkup Penelitian}

Pendekatan yang digunakan dalam penelitian ini adalah deskriptif kuantitatif, yaitu penelitian tentang data yang dikumpulkan dan dinyatakan dalam bentuk angkaangka, meskipun ada juga berupa data kualitatif sebagai pendukungnya. Menurut Retnawati (2016) analisis kuantitatif adalah metode penelitian yang kegiatan analisis datanya meliputi pengolahan dan penyajian data, melakukan perhitungan untuk mendeskripsikan dan melakukan pengujian hipotesis dengan menggunakan uji statistik. Sedangkan metode deskriptif adalah suatu metode yang digunakan untuk menggambarkan atau menganalisis suatu hasil penelitian tetapi tidak digunakan untuk membuat kesimpulan yang lebih luas.

\subsection{Populasi dan Sampel}

Populasi dalam penelitian ini adalah anggota Satuan Polisi Pamong Praja yang ditugaskan pada SOPD Satuan Polisi Pamong Praja Kabupaten Kotawaringin Timur. Jumlah anggota satuan polisi pamong praja yang ada di SOPD Satuan Polisi Pamong Praja sebanyak 113 orang.
Penentuan jumlah sampel dengan menggunakan persamaan Slovin yang dikutip oleh Sarjono dan Julianita (2011), yaitu:

$$
n=\frac{N}{N d^{2}+1}
$$

Keterangan:

$\mathrm{n} \quad=$ Jumlah sampel

$\mathrm{N} \quad=$ Jumlah populasi

$\mathrm{d}=$ Nilai presisi (ketelitian) sebesar 0,05.

Pada penelitian ini, ketelitian atau kesalahan pencuplikan (sampling error) yang digunakan adalah 0,05 sesuai dengan rekomendasi Wirawan (2014). Jumlah dengan perhitungan sebagai berikut:

$$
\begin{aligned}
& n=\frac{113}{113\left(0,05^{2}\right)+1} \\
& n=\frac{139}{139(0,0025)+1} \\
& n=\frac{139}{1,2825} \\
& n=88
\end{aligned}
$$

Jumlah sampel dalam penelitian ini adalah sebanyak 88 orang.

\subsection{Definisi Operasional Variabel Penelitian}

- Variabel Kinerja (Y)

Kinerja adalah unjuk kerja seorang anggota dalam suatu organisasi sesuai dengan wewenang dan tanggung jawab dalam upaya mencapai tujuan organisasi. Kinerja diukur dengan indikator: kuantitas, kualitas, disiplin dan tanggung jawab.

- Variabel Gaya Kepemimpinn $\left(X_{1}\right)$

Gaya kepemimpinan adalah merupakan norma perilaku yang digunakan oleh seseorang Anggota Satpol PP untuk mempengaruhi perilaku orang lain seperti yang ia inginkan untuk mengembangkan lingkungan kerja yang kondusif dan membangun iklim motivasi bagi karyawan sehingga diharapkan akan menghasilkan produktivitas yang tinggi, yang diukur dengan indikator: Kharisma, pengaruh ideal, inspirasi, kemampuan intlektual, dan perhatian individu.

- Variabel Lingkungan Kerja $\left(\mathrm{X}_{2}\right)$

Lingkungan kerja adalah segala sesuatu yang ada di sekitar Anggota SatPol PP pada saat bekerja, yang dapat mempengaruhi dirinya dan pekerjaannya saat bekerja, yang diukur dengan indikator: Penerangan cahaya, sirkulasi udara, tata warna, keamanan, hubungan atasan dan bawahan, hubungan sesama kerja.

- Variabel Pendikan dan Pelatihan $\left(X_{3}\right)$

Pendidikan dan pelatihan merupakan serangkaian kegiatan yang mengutamakan pengetahuan, keterampilan dan peningkatan kemampuan seseorang dalam melaksanakan tugasnya dalam rangka pencapaian 
tujuan organisasi. Indikator yang digunakan untuk mengukur variabel Pendidikan dan Pelatihan yaitu: pelaksanaan, dan implementasi.
Rincian definisi operasional, variabel, indiaktor penilaian serta item yang akan diukur disajikan pada Tabel 1.

Tabel 1. Definisi operasional variabel

\begin{tabular}{|c|c|c|c|c|}
\hline No. & $\begin{array}{c}\text { Variabel/ } \\
\text { Definisi Operasional }\end{array}$ & Indikator & Item & $\begin{array}{l}\text { Kisi-kisi } \\
\text { Kuisioner }\end{array}$ \\
\hline \multirow[t]{6}{*}{1} & \multirow[t]{6}{*}{$\begin{array}{l}\text { Kinerja }(Y), \\
\text { Kinerja adalah unjuk kerja } \\
\text { seorang anggota dalam suatu } \\
\text { organisasi sesuai dengan } \\
\text { wewenang dan tanggung jawab } \\
\text { dalam upaya mencapai tujuan } \\
\text { organisasi. }\end{array}$} & 1. Kualitas & $\begin{array}{l}\text { 1. kualitas kerja sesuai kebutuhan } \\
\text { 2. meminimalkan kesalahan dalam } \\
\text { pekerjaan } \\
\text { 3. ketelitian dalam bekerja } \\
\text { 4. pekerjaan terselesaikan tanpa } \\
\text { bantuan orang lain }\end{array}$ & $\begin{array}{l}\text { Y2 } \\
\text { Y3 } \\
\text { Y4 } \\
\text { Y5 }\end{array}$ \\
\hline & & 2. Kuantitas & $\begin{array}{l}\text { 1. pekerjaan terselesaikan sesuai waktu } \\
\text { yang ditentukan }\end{array}$ & Y6 \\
\hline & & & 2. pekerjaan selesai sesuai target & Y7 \\
\hline & & 3. Disiplin & 1. hadir tepat waktu & $\begin{array}{l}\text { Y8 } \\
\text { yo }\end{array}$ \\
\hline & & A T-nо & 2. mentaati peraturan yang ada & Y9 \\
\hline & & 4. Tanggung jawab & $\begin{array}{l}\text { 1. tanggung jawab terhadap fasilitas } \\
\text { 2. tangung jawab terhadap pekerjaan }\end{array}$ & $\begin{array}{l}\mathrm{Y} 10 \\
\mathrm{Y} 11\end{array}$ \\
\hline \multirow[t]{5}{*}{2} & \multirow{5}{*}{$\begin{array}{l}\text { Gaya Kepemimpinan }\left(\mathrm{X}_{1}\right)_{1} \\
\text { Gaya kepemimpinan adalah } \\
\text { merupakan norma perilaku yang } \\
\text { digunakan oleh seseorang } \\
\text { Anggota SatPol PP untuk } \\
\text { mempengaruhi perilaku orang } \\
\text { lain seperti yang ia inginkan } \\
\text { untuk mengembangkan } \\
\text { lingkungan kerja yang kondusif } \\
\text { dan membangun iklim motivasi } \\
\text { bagi karyawan sehingga } \\
\text { diharapkan akan menghasilkan } \\
\text { produktivitas yang tinggi }\end{array}$} & 1. Kharisma & $\begin{array}{l}\text { 1. pemimpin memiliki kharisma dalam } \\
\text { memimpin }\end{array}$ & GK1 \\
\hline & & 2. Pengaruh ideal & $\begin{array}{l}\text { 1. pemimpin memiliki pengaruh yang } \\
\text { ideal dalam memimpin }\end{array}$ & GK2 \\
\hline & & 3. Inspirasi & $\begin{array}{l}\text { 1. pemimpin dapat menjadi inspirasi } \\
\text { dalam melakukan pekerjaan }\end{array}$ & GK3 \\
\hline & & $\begin{array}{l}\text { 4. Kemampuan } \\
\text { intlektual }\end{array}$ & $\begin{array}{l}\text { 1. pemimpin mempunyai kemampuan } \\
\text { intelektual }\end{array}$ & GK4 \\
\hline & & 5. Perhatian individu & $\begin{array}{l}\text { 1. pemimpin mempunyai perhatian } \\
\text { individu terhadap personil }\end{array}$ & GK5 \\
\hline \multirow[t]{6}{*}{3} & \multirow{6}{*}{$\begin{array}{l}\text { Lingkungan kerja }\left(\mathrm{X}_{2}\right) \\
\text { Lingkungan kerja adalah segala } \\
\text { sesuatu yang ada di sekitar } \\
\text { Anggota SatPol PP pada saat } \\
\text { bekerja, yang dapat } \\
\text { mempengaruhi dirinya dan } \\
\text { pekerjaannya saat bekerja, yang } \\
\text { diukur dengan indikator }\end{array}$} & $\begin{array}{l}\text { 1. Hubungan atasan } \\
\text { dan bawahan }\end{array}$ & $\begin{array}{l}\text { 1. hubungan baik antar sesama rekan } \\
\text { kerja }\end{array}$ & LK1 \\
\hline & & $\begin{array}{l}\text { 2. Hubungan sesama } \\
\text { kerja }\end{array}$ & $\begin{array}{l}\text { 1. hubungan antara atasan dengan } \\
\text { bawahan harmonis }\end{array}$ & LK2 \\
\hline & & 3. Penerangan cahaya & $\begin{array}{l}\text { 1. kantor mempunyai penerangan dan } \\
\text { pencahayaan yang baik }\end{array}$ & LK3 \\
\hline & & 4. Keamanan & $\begin{array}{l}\text { 1. Lingkungan memberikan rasa aman } \\
\text { dalam bekerja }\end{array}$ & LK4 \\
\hline & & 5. Sirkulasi udara & $\begin{array}{l}\text { 1. ruangan mempunyai sirkulasi udara } \\
\text { yang baik }\end{array}$ & LK5 \\
\hline & & 6. Tata warna & $\begin{array}{l}\text { 1. kantor memiliki tata warna yang } \\
\text { menarik dan nyaman dipandang }\end{array}$ & LK6 \\
\hline \multirow[t]{9}{*}{4} & \multirow{9}{*}{$\begin{array}{l}\text { Pendidikan dan Pelatihan (X3), } \\
\text { Pendidikan dan pelatihan } \\
\text { merupakan Serangkaian } \\
\text { kegiatan yang mengutamakan } \\
\text { pengetahuan, keterampilan dan } \\
\text { peningkatan kemampuan } \\
\text { seseorang dalam melaksanakan } \\
\text { tugasnya dalam rangka } \\
\text { pencapaian tujuan organisasi. }\end{array}$} & 1. Pelaksanaan & $\begin{array}{l}\text { 1. perlu untuk mengikuti pendidikan } \\
\text { dan pelatihan }\end{array}$ & PP1 \\
\hline & & & $\begin{array}{l}\text { 2. Instansi tempat bekerja memberikan } \\
\text { kesempatan mengikuti pendidikan }\end{array}$ & PP2 \\
\hline & & & $\begin{array}{l}\text { 3. Materi pendidikan dan pelatihan } \\
\text { sesuai dengan kebutuhan pekerjaan }\end{array}$ & PP3 \\
\hline & & & $\begin{array}{l}\text { 4. Pendidikan dan pelatihan dapat } \\
\text { meningkatkan kinerja }\end{array}$ & PP4 \\
\hline & & & $\begin{array}{l}\text { 5. Pendidikan dan pelatihan dapat } \\
\text { meningkatkan pengetahuan }\end{array}$ & PP5 \\
\hline & & 2. Implementasi & $\begin{array}{l}\text { 1. bermanfaat untuk meningkatkan } \\
\text { kemampuan dan keterampilan }\end{array}$ & PP6 \\
\hline & & & $\begin{array}{l}\text { 2. mampu mengaplikasi-kan materi/ } \\
\text { teori }\end{array}$ & PP7 \\
\hline & & & $\begin{array}{l}\text { 3. memudahkan dalam mengerjakan } \\
\text { tugas }\end{array}$ & PP8 \\
\hline & & & $\begin{array}{l}\text { 4. membantu dalam pengambilan } \\
\text { keputusan }\end{array}$ & PP9 \\
\hline
\end{tabular}




\subsection{Jenis dan Sumber Data Penelitian}

Jenis data yang digunakan dalam penelitian ini adalah data primer dan data sekunder. Data primer diperoleh secara langsung dari sumber asli (tidak melalui sumber perantara) dan data dikumpulkan secara khusus untuk menjawab pertanyaan penelitian yang sesuai dengan keinginan peneliti. Dalam penelitian ini data primer diperoleh dari jawaban responden yang terpilih sebagai sampel dari anggota Satpol PP Kabupaten Kotawaringin Timur.

Adapun data sekunder diperoleh peneliti secara tidak langsung melalui dokumen-dokumen yang ada pada SOPD Satpol PP Kabupaten Kotawaringin Timur.

\subsection{Teknik Pengumpulan Data}

Teknik pengumpulan data yang digunakan dalam penelitian ini adalah dokumentasi, dan penyebaran kuesioner. Teknik dokumentasi, yaitu cara pengumpulan data dengan mempelajari data yang bersumber dari dokumen hasil laporan yang dibuat oleh SOPD Satgpol PP Kabupaten Kotawaringin Timur dan atau Instansi lain yang dapat dipercaya keabsahannya.

Kuesioner adalah metode pengumpulan data dengan memberikan atau menyebarkan daftar pertanyaan kepada responden. Setiap responden diminta pendapatnya dengan memberikan jawaban dari pernyataan-pernyataan yang diajukan. Metode penilaiannya dengan menggunakan checklist, yakni responden tinggal memilih jawaban yang telah disediakan. Sementara itu butir-butir pertanyaan kuesioner dibuat dalam bentuk pilihan ganda, di mana setiap butir pertanyaan terdiri dari lima alternatif jawaban. Kemudian data jawaban para responden diberi skor dengan menggunakan system Skala Likert. Tabel 2 menyajikan lima klasifikasi jawaban yang diberikan dengan pemberian skor.

Tabel 2. Skor item pernyataan

\begin{tabular}{llc}
\hline & Item Pernyataan & Skor \\
\hline SS & = Sangat Setuju & 5 \\
S & $=$ Setuju & 4 \\
RR & $=$ Ragu-ragu & 3 \\
TS & $=$ Tidak Setuju & 2 \\
STS & $=$ Sangat Tidak Setuju & 1 \\
\hline
\end{tabular}

Dipilihnya kriteria penilaian dalam skala Likert (1-5) dikarenakan angka 1 sampai 5 merupakan penilaian yang sudah umum digunakan terutama di Indonesia dan diperoleh data yang bersifat interval dengan skor tertentu. Menggunakan alternatif jawaban yang sama untuk berbagai macam pertanyaan membuat responden dapat memberikan jawaban terhadap berbagai macam pertanyaan dalam waktu yang relatif singkat.

\subsection{Teknik Analisis Data}

Suatu Penelitian membutuhkan analisis data dan interpretasi yang bertujuan menjawab pertanyaan- pertanyaan penelitian dalam rangka mengungkap fenomena sosial tertentu. Analisis data adalah proses penyederhanaan data kedalam bentuk yang lebih mudah dibaca dan diinterpretasikan. Metode yang dipilih untuk menganalisis data harus sesuai dengan pola penelitian dan variabel yang akan diteliti. The Structural Equation Modelling (SEM) dengan metode Partial Least Square (PLS). Statistik digunakan dalam model pengujian Hipotesis.

Adapun penggunaan SEM dalam model dan pengujian hipotesis adalah karena SEM merupakan sekumpulan teknik-teknik statistik yang memungkinkan pengujian sebuah rangkaian hubungan yang relatif rumit secara simultan. Yang dimaksud dengaan model yang rumit adalah model-model simultan yang dibentuk melalui lebih dari satu variabel dependen yang dijelaskan oleh satu atau beberapa variabel independen dan dimana sebuah variabel dependen pada saat yang sama berperan sebagai variabel indipenden bagi hubungan berjenjang lainnya (Ferdinand, 2014).

Untuk mendapatkan gambaran mengenai derajat persepsi responden atas variabel yang akan diteliti, sebuah nilai indeks dapat dikembangkan.

Perumusan untuk menghitung nilai indeks adalah sebagai berikut:

Nilai Indeks $=((\% \mathrm{~F} 1 \times 1)+(\% \mathrm{~F} 2 \times 2)+(\% \mathrm{~F} 3 \times 3)+(\% \mathrm{~F} 4 \times 4)+$ $(\% \mathrm{~F} 5 \times 5)) / 5$

dimana:

F1 adalah Frekuensi responden yang menjawab 1

F2 adalah Frekuensi responden yang menjawab 2, dst

Karena jawaban responden tidak berangkat dari angka 0, tetapi mulai angka 1 hingga 5, maka angka indeks yang dihasilkan akan berangkat dari angka 20 hingga 100 dengan rentang sebesar 80, tanpa angka 0 . Dengan menggunakan kriteria tiga kotak (Three-box method), maka rentang sebesar 80 dibagi tiga akan menghasilkan rentang sebesar rentang sebesar 26,67.rentang tersebut akan digunakan sebagai dasar untuk menentukan indeks persepsi responden terhadap variabel-variabel yang digunakan dalam penelitian ini yaitu sebagai berikut:

$20,00-46,67=$ Rendah

$46,67-73,34=$ Sedang

73,35-100 = Tinggi

Atas dasar pedoman ini, maka indeks persepsi responden terhadap variabel-variabel penelitian yang diajukan dalam model dapat diteliti dan dideskripsikan.

\subsection{Penilaian Reliabilitas}

Pendekatan untuk penilaian reliabilitas dengan menggunakan composite reability dan variance extrad untuk setiap variabel. Realitas merupakan ukuran internal consistency. Indikator dari setiap variabel, hasil reliabilitas yang tinggi akan memberikan keyakinan bahwa jawaban partisipan terhadap semua indicator konsisten dengan pengukurannya. 


\subsection{Penilaian Validitas}

Pengukuran validitas digunakan untuk menilai sah atau valid tidaknya suatu kuisioner. Suatu kuisioner dikatakan valid jika pertanyaan kuisioner tersebut mampu mengungkapkan suatu yang akan diukur oleh kuisioner tersebut confirmatory Factor Analysis (CFA) digunakan untuk menilai validitas masing-masing variabel yang merupakan manisfestasi dari indicator. Semua loading dari variabel menunjukkan hasil yang signifikan yaitu t Statistik .>1,645 (1-tailed) atau t statistik $>1,96$ (92-tailed), maka masing-masing indkator pertanyaan adalah valid (Ghozali, 2008).

\subsection{Uji Hipotesis}

Pengujian hipotesis penelitian dilakukan dengan pendekatan Structural Equation Model (SEM) dengan menggunakan software Partial Least Square (PLS). PLS adalah model berbasis komponen atau varian. Menurut Ghozali (2008), PLS merupakan pendekatan alternatif yang bergeser dari pendekatan SEM berbasis kovarian menjadi berbasis varian. SEM yang berbasis kovarian umumnya menguji kausalitas/teori sedangkan PLS lebih bersifat perfective model.

PLS merupakan metode analisis yang powerfull (Word, 1985 dalam Ghozali 2008) karena tidak didasarkan pada banyak asumsi. Misalnya data harus terdistribusi normal, sampel tidak harus besar. Selain dapat digunakan untuk menjelaskan ada tidaknya hubungan antara variabel. PLS tidak sekaligus menganalisis variabel yang dibentuk dengan indicator refleksif dan normative. Hal ini tidak dapat dilakukan oleh SEM yang berbasis kovarian karena akan menjadi unidentified model. Dalam menganalisis menggunakan PLS ada 2 (dua) hal yang dilakukan, yaitu:

- Memulai outer model atau measurement model

Ada 3 kriteria untuk menilai outer model yaitu covergent validity, discriminant validity dan decomposite realibility. Convergent validity dari model pengukuran dengan refleksif individual dikatakan tinggi jika berkolerasi lebih dari 0,70 dengan variabel yang di ukur. Discriminant Validity dari model pengukuran dengan refleksif indicator dinilai berdasarkan cross loading pengukuran dengan variabel. Metode lain untuk menilai Discriminant validity adalah membandigkan nilai root of Averange variant Extracted (AVE). Setiap setiap variabel dengan korelasi antar variabel dengan variabel lainnya dalam model.Jika nilai AVE setiap variabel lebih besar dari pada nilai korelasi antar variabel dengan variabel lainnya dalam model maka dikatakan memiliki nilai discriminant validity yang baik (Fornel dan Loker ,1981 dalam Ghozali 2008).

\section{- Menilai Inner Model atau Structural Model}

Pengujian Inner model atau structural model dilakukan untuk melihat hubungan antar variabel, nilai signifikansi dan R-square dari model penelitian. Dalam menilai model dengan PLS simulai dengan melihat R-square untuk setiap variabel dependent Perubahan nilai R-square dapat digunakan untuk menilai pengaruh variabel indipenden tertentu terhadap variabel dependen apakah mempunyai pengaruh yang substantif.

\subsection{Kriteria Penerimaan dan Penolakan Hipotesis}

Pengambilan keputusan atas penerimaan atau penolakan hipotesis dilakukan dengan ketentuan sebagai berikut:

- Melihat nilai Outer weigh

Nilai outer weigh masing-masing indikator dan nilai signifikansinya.

Nilai weigh yang disarankan adalah diatas 0,5 (positif) jika:

$\Rightarrow$ t-statistik diatas 1,282 untuk $\mathrm{p}<0,10$

$\Rightarrow$ t-statistik diatas 1,645 untuk $\mathrm{p}<0,05$

$\Rightarrow$ t-statistik diatas 2,326 untuk $\mathrm{p}<0,01$ (one-tailed)

Kemudian Nilai weigh yang disarankan adalah diatas 0,5 (positif) jika:

$\Rightarrow \mathrm{t}$-statistik diatas 1,645 untuk $\mathrm{p}<0,10$

$\Rightarrow$ t-statistik diatas 1,960 untuk $\mathrm{p}<0,05$

$\Rightarrow$ t-statistik diatas 2,576 untuk p $<0,10$ (two-tailed) Indikator yang memiliki nilai dibawah ketentuan tersebut harus di drop dari model dan kemudian dilakukan penguian ulang.

- Melihat nilai inner weigh dari hubungan antar variabel Nilai weigh dari hubungan tersebut harus arah positif jika:

$\Rightarrow$ Nilai t-statistik diatas 1,282 untuk $\mathrm{p}<0,10$

$\Rightarrow$ Nilai t-statistik diatas 1,645 untuk $\mathrm{p}<0,05$

$\Rightarrow$ Nilai t-statistik diatas 2,326 untuk $\mathrm{p}<0,01$ (onetailed)

Kemudian Nilai weigh dari hubungan tersebut harus menunjukkan arah positif jika :

$\Rightarrow$ Nilai t-statistik diatas 1,645 untuk $\mathrm{p}<0,10$

$\Rightarrow$ Nilai t-statistik diatas 1,960 untuk $\mathrm{p}<0,05$

$\Rightarrow$ Nilai t-statistik diatas 2,576 untuk p<0,10 (twotailed)

- Hipotesis alternatif $(\mathrm{Ha})$ diterima jika nilai weigh dari hubungan antar variabel menunjukkan arah positif dengan nilai T statistik jika:

$\Rightarrow$ Nilai t-statistik diatas 1,282 untuk $\mathrm{p}<0,10$

$\Rightarrow$ Nilai t-statistik diatas 1,645 untuk $\mathrm{p}<0,05$

$\Rightarrow$ Nilai t-statistik diatas 2,326 untuk $\mathrm{p}<0,05$ dan 2,576 untuk $p<0,01$ ( two-tailed)

Sebaliknya Ho gagal untuk ditolak jika nilai weigh dari hubungan antar variabel menunjukkan arah negatif jika:

$\Rightarrow$ Nilai t-statistik dibawah 1,282 untuk $\mathrm{p}<0,10$

$\Rightarrow$ Nilai t-statistik dibawah 1,645 untuk $\mathrm{p}<0,01$

$\Rightarrow$ Nilai t-statistik dibawah 1,960 untuk $\mathrm{p}<0,05$ dan 2,576 untuk $p<0,01$ (two-tailed) 
Adapun nilai t-tabel yang ditentukan dalam penelitian ini adalah sebesar 1,645 untuk signifikansi $p<0,05$ (one-tailed) dan 1,960 dengan tingkat signifikansi 0,05 (two-tailed). Selanjutnya nilai t-tabel tersebut dijadikan sebagai nilai cut-off untuk penerimaan atau penolakan hipotesis penelitian.

\section{HASIL}

\subsection{Gambaran Umum Objek Penelitian}

Analisis terhadap kebutuhan perangkat daerah menghendaki adanya evaluasi terhadap kondisi eksisting organisasi perangkat daerah. Hasil evaluasi akan mengakibatkan perubahan organisasi perangkat daerah, berupa pembentukan unit baru, penggabungan unit-unit yang sudah ada, penghapusan unit-unit yang sudah ada, dan perubahan fungsi-fungsi unit yang sudah ada, baik pada Sekretariat Daerah, Dinas Daerah, dan Lembaga Teknis Daerah.

Satpol PP dibentuk berdasarkan Pasal 255 UndangUndang Nomor 23 Tahun 2014 tentang Pemerintahan Daerah Satuan Polisi Pamong Praja. Di era otonomi daerah, peran Satuan Polisi Pamong Praja (Satpol PP) bukan saja makin luas, tetapi juga makin strategis sebagai bagian dari perangkat daerah yang bertugas untuk ikut membantu dan menjamin proses penegakan Peraturan daerah serta pemeliharaan ketertiban dan keamanan masyarakat. Selain itu juga kedudukan Satpol PP Kabupaten Kotawaringin Timur berkedudukan di ibukota Kabupaten (Sampit) yang dimana di kota Sampit tersebut merupakan pusat kegiatan pemerintahan dan juga dimana tingkat konflik sangat relatif besar antara lain permasalahan budaya, sosiologi, ekonomi, ketertiban dan ketentraman masyarakat.
Susunan organisasi Satpol PP Kabupaten Kotawaringin Timur adalah tipe $\mathrm{B}$, terdiri atas:

1) Kepala Satuan

2) Subbagian Tata Usaha

3) Seksi Penegakan Peraturan Perundang-undangan Daerah

4) Seksi Ketertiban Umum dan Ketentraman Masyarakat

5) Seksi Pengembangan Kapasitas

6) Seksi Sarana dan Prasarana

7) Seksi Perlindungan Masyarakat

8) Kelompok Jabatan Fungsional.

\subsection{Karakteristik Responden}

Dalam penelitian ini telah disebarkan kuesioner kepada 88 anggota Satpol PP Kabupaten Kotawaringin Timur. Adapun karakteristik responden menurut jenis kelamin disajikan pada Tabel 3.

Tabel 3. Karakteristik responden menurut jenis kelamin

\begin{tabular}{llcc}
\hline No. & Jenis Kelamin & Jumlah (orang) & Persentase (\%) \\
\hline 1 & Laki-laki & 64 & 72,72 \\
2 & Perempuan & 24 & 27,28 \\
& Jumlah & 88 & 100,00 \\
\hline
\end{tabular}

\subsection{Analisis Deskriptif}

Tabel 4 dan Tabel 5 adalah deskripsi pola data yang merupakan keseluruhan dari 88 anggota Satpol PP Kabupaten Kotawaringin Timur. Tabel 4 menjelaskan deskripsi rata-rata (mean), minimal (min), maksimal (max) pada indikator di setiap variabel. Temuan ini bermanfaat untuk dapat lebih memahami kondisi disetiap indikator dan sebagai dasar argument untuk temuan yang lebih lanjut.

Tabel 4. Deskriptif statistik gaya kepemimpinan (X1)

\begin{tabular}{clccc}
\hline No. & \multicolumn{1}{c}{ Kuesioner } & Mean & Min & Max \\
\hline 1 & Pemimpin memiliki kharisma dalam memimpin & 4,318 & 3 & 5 \\
2 & Pemimpin memiliki pengaruh yang ideal dalam memimpin & 4,330 & 3 & 5 \\
3 & Pemimpin dapat menjadi inspirasi dalam melakukan pekerjaan & 4,216 & 3 & 5 \\
4 & Pemimpin mempunyai kemampuan intelektual & 4,193 & 2 & 5 \\
5 & Pemimpin mempunyai perhatian individu terhadap personil & 4,182 & 2 & 5 \\
\hline & Nilai Rata-rata Variabel & $\mathbf{4 , 2 4 8}$ & $\mathbf{3}$ & $\mathbf{5}$ \\
\hline
\end{tabular}

Tabel 5. Deskriptif statistik lingkungan kerja (X2)

\begin{tabular}{clccc}
\hline No. & \multicolumn{1}{c}{ Kuesioner } & Mean & Min & Max \\
\hline 1 & Hubungan baik antara sesama rekan kerja & 4,216 & 2 & 5 \\
2 & Hubungan antara atasan dengan bawahan harmonis & 4,182 & 2 & 5 \\
3 & Kantor mempunyai penerangan dan pencahayaan yang baik & 4,148 & 2 & 5 \\
4 & Lingkungan memberikan rasa aman dalam bekerja & 4,193 & 2 & 5 \\
5 & $\begin{array}{l}\text { Ruangan mempunyai sirkulasi udara yang baik } \\
\text { Insentif yang diberikan telah disesuaikan dengan beban kerja yang } \\
\text { dilaksanakan }\end{array}$ & 4,182 & 2 & 5 \\
\hline & Nilai rata-rata Variabel & 4,307 & 3 & 5 \\
\hline
\end{tabular}


Pada Tabel 4 tampak bahwa jawaban responden memiliki variasi yang sangat lebar ditunjukkan dengan nilai minimal 2 (tidak setuju) dan maksimal 5 (sangat setuju). Variabel Gaya Kepemimpinan (X1) berisi 5 indikator. Hasil menunjukkan bahwa nilai rata-rata variabel dari Gaya Kepemimpinan (X1) memiliki niali 4,248 (setuju). Hasil tersebut menunjukkan yang bahwa responden setuju dengan setiap pernyataan dalam kuesioner tentang gaya kepemimpinan.

Tabel 5 menyajikan hasil deskriptif variabel Lingkungan Kerja (X2) yang memiliki variasi tinggi dengan nilai minimal 2 (tidak setuju) dan nilai maksimal 5 (sangat setuju). Nilai rata-rata (mean) semua indikator memiliki nilai mean variabel sebesar 4,205. Hasil ini menjelaskan bahwa 88 responden rata-rata setuju dengan pernyataan dalam kuesioner tersebut.
Tabel 6 menjelaskan bahwa 88 responden memiliki variasi jawaban yang tinggi dengan nilai minimal 2 (tidak setuju) dan maksimal 5 (sangat setuju). Variabel pendidikan pelatihan (X3) berisi 9 indikator. Hasil ini mengindikasikan bahwa nilai mean variabel sebesar 4,265. Dengan kata lain, temuan ini menggambarkan bahwa 88 responden rata-rata berpendapat setuju atas semua pertanyaan yang berkaitan dengan pendidikan pelatihan.

Tabel 7 menyajikan hasil deskriptif variabel kinerja (Y) yang memiliki variasi tinggi dengan nilai minimal 2 (tidak setuju) dan nilai maksimal 5 (sangat setuju). Nilai rata-rata (mean) variabel memiliki nilai 4,249. Hasil ini menjelaskan bahwa 88 responden rata-rata setuju dengan setiap pernyataan dalam kuesioner tersebut.

Tabel 6. Deskriptif statistik pendidikan dan pelatihan (X3)

\begin{tabular}{|c|c|c|c|c|}
\hline No. & Kuesioner & Mean & Min & Max \\
\hline 1 & $\begin{array}{l}\text { Anda merasa perlu untuk mengikuti pendidikan dan pelatihan (seperti } \\
\text { bimbingan teknis diklat atau semacamnya) untuk menunjang pekerjaan anda }\end{array}$ & 4,398 & 3 & 5 \\
\hline 2 & $\begin{array}{l}\text { Instansi tempat anda bekerja memberikan anda kesempatan mengikuti } \\
\text { pendidikan (seperti bimbingan teknis diklat atau semacamnya) untuk } \\
\text { mendukung pekerjaan anda }\end{array}$ & 4,352 & 3 & 5 \\
\hline 3 & $\begin{array}{l}\text { Materi pendidikan dan pelatihan yang diberikan telah sesuai dengan } \\
\text { kebutuhan pekerjaan }\end{array}$ & 4,295 & 2 & 5 \\
\hline 4 & Pendidikan dan pelatihan dapat meningkatkan kinerja & 4,273 & 2 & 5 \\
\hline 5 & $\begin{array}{l}\text { Pendidikan dan pelatihan yang anda ikuti dapat meningkatkan pengetahuan } \\
\text { dalam pekerjaan anda }\end{array}$ & 4,239 & 3 & 5 \\
\hline 6 & $\begin{array}{l}\text { Pendidikan dan pelatihan sangat bermanfaat untuk meningkatkan } \\
\text { kemampuan dan keterampilan anda }\end{array}$ & 4,216 & 3 & 5 \\
\hline 7 & $\begin{array}{l}\text { Setelah mengikuti pendidikan dan pelatihan, anda mampu mengaplikasikan } \\
\text { semua materi/teori yang diterima dalam pekerjaan anda }\end{array}$ & 4,148 & 3 & 5 \\
\hline 8 & $\begin{array}{l}\text { Metode yang digunakan dalam pendidikan dan pelatihan (seperti bimbingan } \\
\text { teknis diklat atau semacamnya) memudahkan dalam mengerjakan tugas } \\
\text { yang diberikan }\end{array}$ & 4,216 & 3 & 5 \\
\hline 9 & $\begin{array}{l}\text { Pendidikan dan pelatihan membantu anda dalam pengambilan keputusan } \\
\text { dengan baik }\end{array}$ & 4,250 & 2 & 5 \\
\hline \multicolumn{2}{|r|}{ Nilai Rata-rata Variabel } & 4,265 & 2 & 5 \\
\hline
\end{tabular}

Tabel 7. Deskriptif statistik kinerja pegawai $(\mathrm{Y})$

\begin{tabular}{clrrr}
\hline No. & Kuesioner & Mean & Min & Max \\
\hline 1 & Anda menjalankan target kerja yang telah ditetapkan instansi & 4,318 & 2 & 5 \\
2 & Anda merasa senang dan puas dengan hasil kerja yang dicapai & 4,375 & 3 & 5 \\
3 & Anda jarang melakukan kesalahan dalam melaksanakan tugas & 4,307 & 2 & 5 \\
4 & Anda selalu meneliti kembali setiap tugas yang diberikan sebelum & 4,057 & 2 & 5 \\
5 & disampaikan ke atasan & 4,418 & 3 & 5 \\
6 & Anda mampu menyelesaikan pekerjaan tanpa bantuan orang lain & 4,205 & 3 & 5 \\
7 & yang telah ditentukan & 4,205 & 3 & 5 \\
8 & Pengetahuan akan pekerjaan dapat membantu anda dalam mengatasi & 4,227 & 3 & 5 \\
9 & Anda selalu hadir tepat waktu & 4,182 & 3 & 5 \\
10 & Anda mentaati peraturan yang berlaku di instansi & 4,261 & 3 & 5 \\
11 & Anda bertanggungjawab terhadap fasilitas kantor $\quad$ Mean Variabel & 4,193 & 3 & 5 \\
\hline
\end{tabular}




\subsection{Pengujian Outer Model}

Pada tahap awal, estimasi model outer model dijalankan untuk menguji hubungan indikator dengan variabel latennya. Uji ini untuk memastikan kelayakan dari setiap indikator, yaitu indikator harus memiliki validitas dan reliabilitas yang baik. Evaluasi outer model pada penelitian dijalankan sebanyak 3 (tiga) kali dengan asumsi nilai loading factor harus lebih besar dari 0,6.

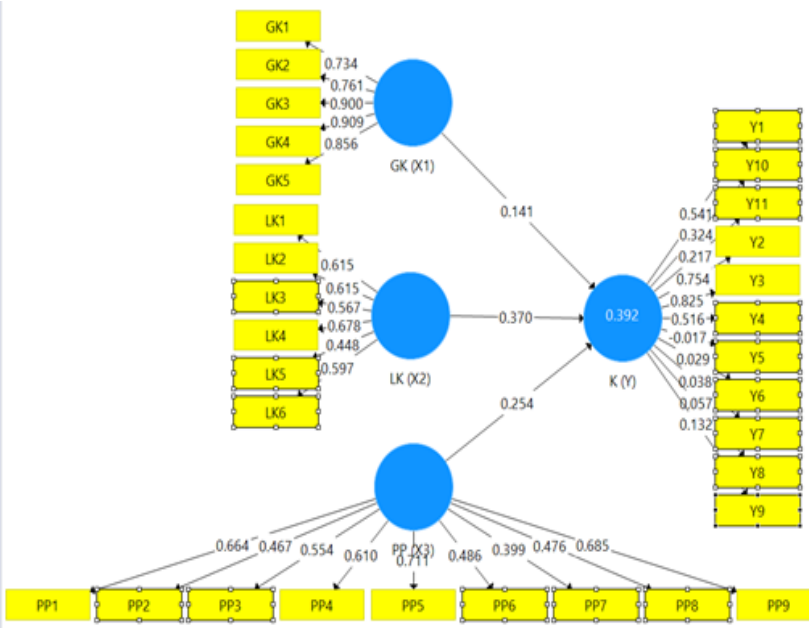

Gambar 1. Pengujian outer model tahap 1

Pada pengujian ke 1 (Gambar 1) terdapat indikator yang memiliki nilai loading factor pada kisaran $<0,6$ dan harus dieliminasi. Indikator yang dieliminasi dan harus di drop adalah refleksi variabel lingkungan kerja (X2) yaitu LK3, LK5, dan LK yang memiliki nilai $<0,6$.

Sementara itu, refleksi dari variabel pendidikan pelatihan (X3) juga terdapat indikator yang memiliki nilai loading factor pada kisaran $<0,6$ dan harus dieliminasi, antara lain PP2, PP3, PP6, PP7, dan PP8.

Indikator dari variabel kinerja $(\mathrm{Y})$ juga memiliki nilai loading factor $<0,6$ dan harus dieliminasi. Indikator yang

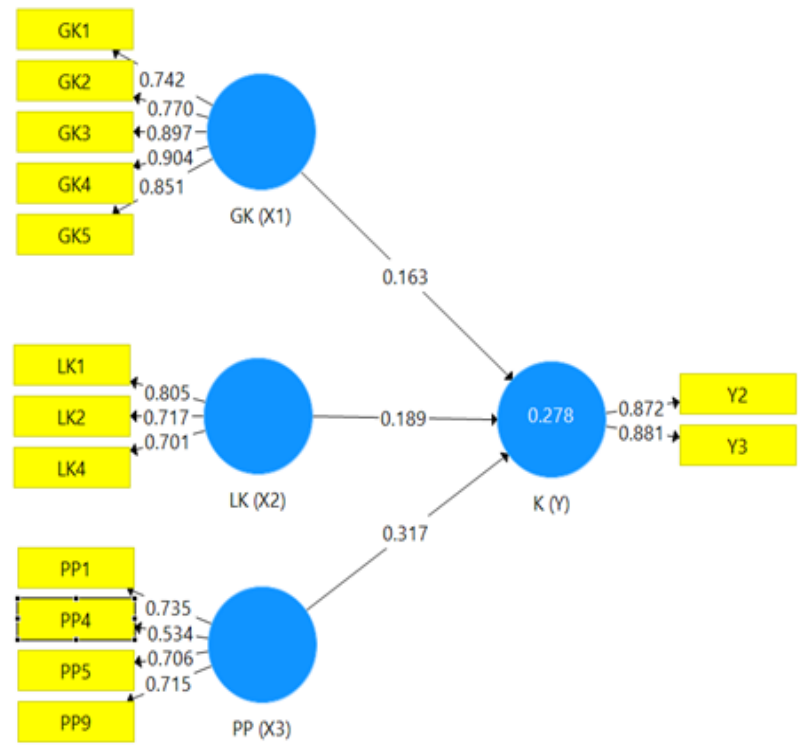

Gambar 2. Pengujian outer model tahap 2 dieliminasi dan harus di drop yaitu $Y 1, Y 4, Y 5, Y 6, Y 7, Y 8$, Y9, Y10 dan Y11. Dengan demikian, model harus dijalankan ulang atau diperlukan pengujian outer model ke 2 untuk memastikan bahwa semua indikator memiliki nilai $>0,6$.

Pada pengujian outer model tahap ke 2 (Gambar 2) tampak bahwa refleksi dari variabel pendidikan pelatihan (X3) masih terdapat indikator yang memiliki nilai loading factor pada kisaran <0,6 dan harus dieliminasi, yaitu PP4. Dengan demikian, model harus dijalankan ulang atau diperlukan pengujian outer model ke 3 untuk memastikan bahwa semua indikator memiliki nilai $>0,6$.

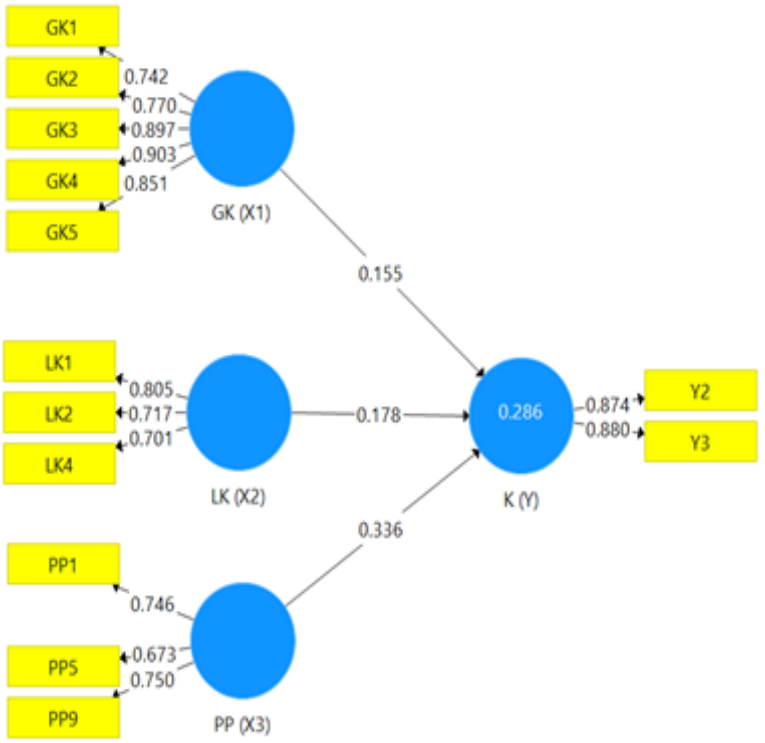

Gambar 3 Pengujian outer model tahap 3

Pada pengujian outer model tahap ke 3 (Gambar 3) tampak bahwa variabel semua indikator memiliki nilai lebih besar dari 0,6. Variabel Gaya Kepemimpinan (X1) menyisakan 5 indikator. Variabel Lingkungan Kerja (X2) tersisa sebanyak 3 indikator. Variabel Pendidikan Pelatihan (X3) menyisakan 3 indikator. Selanjutnya variabel kinerja $(Y)$ menyisakan 2 indikator. Dengan demikian, dalam model penelitian ini tersisa 13 indikator yang layak dilakukan pengujian untuk tahapan selanjutnya.

\subsection{Uji Validitas}

Tabel 8 adalah convergent validity yang menunjukkan bahwa semua indikator memiliki nilai outer loading $>0,6$. Tampak bahwa semua indikator disemua variabel memiliki nilai outer loading lebih besar dari 0,6 bahkan lebih besar dari 0,7. Bukti empiris ini menunjukkan bahwa semua indikator dalam model ini dapat dikatakan memiliki validitas yang baik. Kuesioner yang merupakan refleksi dari pendapat responden didalam indikator yang dijadikan sebagai alat ukur dapat mengestimasi variabelnya masing-masing dengan baik dan secara tepat. 
Tabel 8. Outer loading

\begin{tabular}{ccccc}
\hline $\begin{array}{c}\text { Item } \\
\text { Indikator }\end{array}$ & $\begin{array}{c}\text { Gaya } \\
\text { Kepemim } \\
\text { pinan } \\
(\mathbf{X 1 )}\end{array}$ & $\begin{array}{c}\text { Lingku } \\
\text { ngan } \\
\text { Kerja } \\
(\mathbf{X 2})\end{array}$ & $\begin{array}{c}\text { Pendidikan } \\
\text { Pelatihan } \\
\text { (X3) }\end{array}$ & $\begin{array}{c}\text { Kinerja } \\
(\mathbf{Y})\end{array}$ \\
\hline GK1 & 0,742 & & & \\
GK2 & 0,770 & & & \\
GK3 & 0,897 & & & \\
GK4 & 0,903 & & & \\
GK5 & 0,851 & & & \\
LK1 & & 0,805 & & \\
LK2 & & 0,717 & & \\
LK4 & & 0,701 & & \\
PP1 & & & 0,746 & \\
PP5 & & & 0,673 & \\
PP9 & & & 0,750 & \\
Y2 & & & & 0,874 \\
Y3 & & & & \\
\hline
\end{tabular}

\subsection{Uji Reliabilitas}

Bukti hasil SEM-PLS pada tabel 9 menunjukkan bahwa nilai composite reliability lebih tinggi dari batas toleransi 0,6. Sementara itu, nilai AVE lebih tinggi dari batasan yang direkomendasikan yaitu $>0,5$. Hasil ini menunjukkan bahwa semua konstruk atau variabel dalam penelitian ini memiliki reliabilitas yang baik.

Tabel 9. Uji reliabilitas

\begin{tabular}{lcc}
\hline \multicolumn{1}{c}{ Variabel } & $\begin{array}{c}\text { Composite } \\
\text { Reliability }\end{array}$ & $\begin{array}{c}\text { Average } \\
\text { Variance } \\
\text { Extracted } \\
\text { (AVE) }\end{array}$ \\
\hline Gaya Kepemimpinan (X1) & 0,920 & 0,698 \\
Lingkungan Kerja (X2) & 0,869 & 0,768 \\
Pendidikan Pelatihan (X3) & 0,786 & 0,551 \\
Kinerja (Y) & 0,767 & 0,524 \\
\hline
\end{tabular}

\subsection{Pengujian Inner Model}

Gambar 4 merupakan hasil uji inner model pada penelitian ini Selanjutnya, inner model di uji menggunakan menggunakan SEM-PLS dengan menjalankan bootstrapping.

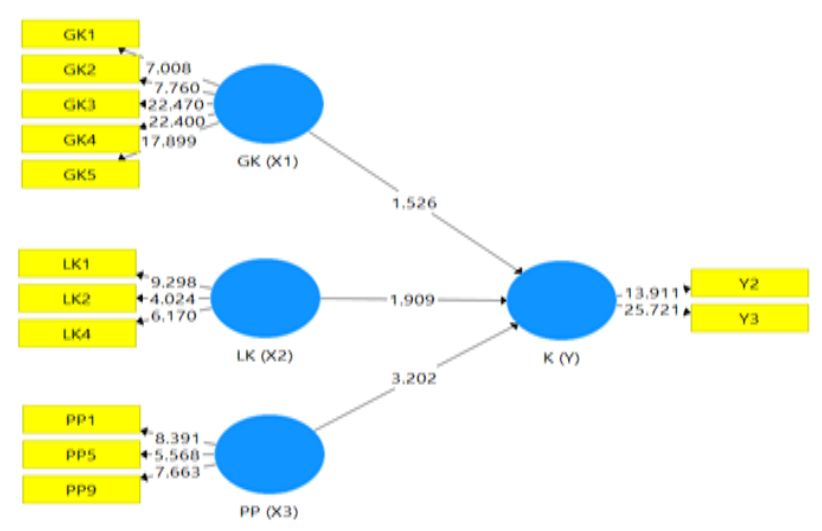

Gambar 4. Inner model

\subsection{Pengujian Hipotesis}

Nilai signifikansi pada P-value dan T-statistik merupakan ukuran untuk melihat signifikansi pengaruh variabel independen terhadap variabel dependen. Berdasarkan tingkat kepercayaan 95\% maka taraf signifikansi 5\% dan $P$-value harus $<0,05$. Tabel 10 menyajikan bukti empiris temuan pada hubungan tersebut dan sub-bab berikutnya dibawah ini menyajikan penjelasan dari setiap pengujian hipotesis.

Tabel 10. Path coefficients

\begin{tabular}{lccc}
\hline \multicolumn{1}{c}{ Pengaruh Langsung } & Koef. & $\begin{array}{c}\boldsymbol{P} \text { - } \\
\text { value }\end{array}$ & Hipotesis \\
\hline $\begin{array}{l}\text { Gaya Kepemimpinan }(\mathrm{X} 1) \\
->\text { Kinerja }(\mathrm{Y})\end{array}$ & 0,155 & 0,064 & $\mathrm{H} 1$ ditolak \\
$\begin{array}{l}\text { Lingkungan Kerja }(\mathrm{X} 2)-> \\
\text { Kinerja (Y) }\end{array}$ & 0,178 & 0,028 & $\mathrm{H} 2$ diterima \\
$\begin{array}{l}\text { Pendidikan Pelatihan }(\mathrm{X} 3) \\
\text {-> Kinerja }(\mathrm{Y})\end{array}$ & 0,336 & 0,001 & $\mathrm{H} 3$ diterima \\
\hline
\end{tabular}

- Pengujian Hipotesis 1: pengaruh gaya kepemimpinan terhadap kinerja

Tabel 10 baris 1 menyajikan bukti empiris bahwa nilai $P$-value $0,064>0,05$ yang berarti tidak signifikan. Temuan ini menolak Hipotesis 1 bahwa gaya kepemimpinan (X1) berpengaruh signifikan terhadap kinerja $(Y)$ dengan taraf signifikansi $>5 \%$. Dengan demikian, perubahan pada gaya kepemimpinan (X1) tidak dapat secara signifikan menjelaskan perubahan dari kinerja $(\mathrm{Y})$.

- Pengujian Hipotesis 2: pengaruh lingkungan kerja (X2) terhadap kinerja ( $Y$ )

Tabel 10 baris 2 memberikan bukti bahwa nilai $P$ value adalah $0,028<0,05$. Hasil ini menerima Hipotesis 2 bahwa lingkungan kerja (X2) berpengaruh signifikan terhadap kinerja $(Y)$ dengan taraf signifikansi 5\%. Temuan ini juga menggambarkan bahwa variasi dari lingkungan kerja (X2) dapat menjelaskan variasi dari kinerja $(\mathrm{Y})$.

- Pengujian Hipotesis 3: pengaruh pendidikan pelatihan (X3) terhadap kinerja $(\mathrm{Y})$

Tabel 10 baris 3 menunjukkan bahwa nilai $P$ value 0,001<0,05 yang berarti signifikan (Hipotesis 3 diterima). Hasil ini menerima hipotesis 3 bahwa pendidikan pelatihan (X3) berpengaruh signifikan terhadap kinerja $(Y)$ dengan taraf signifikansi 5\%. Dengan kata lain, berbagai variasi pendidikan pelatihan (X3) mampu menjelaskan perubahan dari kinerja $(\mathrm{Y})$ secara signifikan.

\section{PEMBAHASAN}

\subsection{Pengaruh Gaya Kepemimpinan terhadap Kinerja}

Pengujian hipotesis menunjukkan bahwa Gaya Kepemimpinan tidak berpengaruh signifikan terhadap 
kinerja. Dengan kata lain, perubahan Gaya Kepemimpinan tidak dapat menyebabkan perubahan pada kinerja.

Berdasarkan temuan empiris, hal ini terjadi karena Gaya Kepemimpinan yang direfleksikan dengan Kharisma, pengaruh ideal, inspirasi, kemampuan intlektual, dan perhatian individu tidak mampu mempengaruhi perubahan pada kinerja, artinya Gaya kepemimpinan yang diterapkan tidak mempengaruhi kinerja dikarenakan kinerja tidak terlalu memperhatikan gaya kepemimpinan

Temuan ini sejalan dengan penelitian Haryanto (2017), yang menyatakan bahwa gaya kepemimpinan tidak berpengaruh terhadap kinerja.

\subsection{Pengaruh Lingkungan Kerja terhadap Kinerja}

Hasil penelitian membuktikan bahwa lingkungan kerja berpengaruh signifikan terhadap kinerja. Hasil ini membuktikan semakin baik lingkungan kerja yang ada dalam bentuk hubungan baik antara rekan kerja dan atasan serta rasa aman akan berpengaruh terhadap kinerja. Kondisi lingkungan kerja yang baik adalah salah satu faktor penunjang produktivitas pegawai yang pada akhirnya berdampak pada kenaikan tingkat kinerja pegawai. Artinya lingkungan kerja akan meningkatkan kinerja pegawai. lingkungan kerja yang kondusif dapat menunjang kinerja pegawai dalam melaksanakan pekerjaannya, agar hasil kerja yang diperoleh dapat tercapai secara optimal.

Hasil penelitian ini juga sejalan dengan Handayani (2019), dan Tuwan (2013), bahwa lingkungan kerja berpengaruh terhadap kinerja.

\subsection{Pengaruh Pendidikan Pelatihan terhadap Kinerja}

Hasil penelitian membuktikan bahwa pendidikan pelatihan berpengaruh signifikan terhadap kinerja. Dengan kata lain pentingnya pendidikan dan pelatihan dalam organisasi adalah perbaikan kinerja pegawai yang meliputi knowledge dan ketrampilan yang mendukung, serta pembentukan sikap setiap para pegawai sesuai yang diinginkan oleh organisasi. Dengan mengikuti pendidikan dan pelatihan merupakan proses untuk meningkatkan kemampuan sumber daya manusia serta untuk memperbaiki keterampilan kerja pegawai untuk membantu tercapainya tujuan dari organisasi. Programprogram yang ada dalam pendidikan dan pelatihan akan memberi manfaat kepada lembaga dan pegawai itu sendiri. Lembaga akan memperoleh manfaat seperti peningkatan produktivitas kerja, stabilitas kerja, dan fleksibilitas kerja sehingga pegawai dapat menyesuaikan diri dengan keadaan yang semakin meningkat.

Penelitian ini sejalan dengan penelitian yang dilakukan Darmawan et al. (2017), Handayani (2019), Tuwan (2013), Sunarto (2012), dan Dianantari dan Yuesti (2019) (2009); bahwa pendidikan dan pelatihan berpengaruh terhadap kinerja.

\section{KESIMPULAN DAN SARAN}

Berdasarkan bukti empiris pengujian statistik dan pembahasan maka dapat ditarik beberapa kesimpulan penelitian ini sebagai berikut:

1. Gaya kepemimpinan (X1) tidak berpengaruh signifikan terhadap kinerja $(\mathrm{Y})$ dengan taraf signifikansi $>5 \%$. Dengan demikian, perubahan pada gaya kepemimpinan (X1) tidak dapat secara signifikan menjelaskan perubahan dari kinerja $(Y)$.

2. Pendidikan pelatihan (X3) berpengaruh signifikan terhadap kinerja $(Y)$ dengan taraf signifikansi $5 \%$. Dengan kata lain, berbagai variasi pendidikan pelatihan (X3) mampu menjelaskan perubahan dari kinerja $(Y)$ secara signifikan.

3. Lingkungan kerja (X2) berpengaruh signifikan terhadap kinerja ( $Y$ ) dengan taraf signifikansi 5\%. Temuan ini juga menggambarkan bahwa variasi dari lingkungan kerja (X2) dapat menjelaskan variasi dari kinerja $(Y)$.

Penelitian ini mengkonfirmasi bahwa variabel gaya kepemimpinan (X1) memiliki hasil yang paling rendah di antara variabel bebas lainnya. Untuk meningkatkan kinerja pegawai, pimpinan harus benar-benar mempunyai perilaku seorang pemimpin. Untuk memperkuat model kepemimpinan yang positif, perlu dilakukan pengembangan SDM baik dari segi kepemimpinan maupun kompetensi. Dengan meningkatnya kualitas kepemimpinan dan kompetensi baik pimpinan maupun bawahan maka akan berimplikasi terhadap peningkatan kinerja pegawai. Dengan memperkuat model kepemimpinan yang positif dapat membuat suasana kerja menjadi lebih nyaman, pegawai merasa engage, bersemangat ketika bekerja dan bersedia mengerahkan seluruh energinya untuk menyelesaikan tugas yang diberikan.

\section{DAFTAR PUSTAKA}

Darmawan, Y. Y., Supartha, W. G., \& Rahyuda, A. G. (2017). Pengaruh pelatihan terhadap motivasi kerja dan kinerja di Prama Sanur Beach-Bali. E-Jurnal Ekonomi dan Bisnis Universitas Udayana, 1265-1290.

Dianantari, N. M. Y., \& Yuesti, A. (2019). Pengaruh pelatihan, motivasi, dan budaya kerja terhadap kinerja karyawan di PDAM Tirta Mangutama Kabupaten Badung. JSAM (Jurnal Sains, Akuntansi dan Manajemen), 1(4), 637-647.

Ghozali, I. (2008). Structural equation modeling: Metode alternatif dengan partial least square (PLS). Badan Penerbit Universitas Diponegoro.

Handayani, D. (2019). Pengaruh pendidikan dan pelatihan, motivasi, serta lingkungan kerja terhadap kinerja guru SMK Negeri Banyuasin. Jurnal Ilmu Manajemen, 6(2), 140-150. 
Retnawati, H. (2016). Analisis kuantitatif instrumen penelitian. Yogyakarta: Parama Publishing.

Sarjono, H., \& Julianita, W. (2011). SPSS vs LISREL: sebuah pengantar, aplikasi untuk riset. Jakarta: Salemba Empat.

Sulaiman, M. O. (2020). Pengaruh pelatihan dan lingkungan kerja terhadap kinerja pegawai BPBD Kota Kediri. Revitalisasi, 7(2), 172-179.
Tuwan, F. (2013). Pengaruh pendidikan dan pelatihan, lingkungan kerja dan gaya kepemimpinan terhadap kinerja anggota Satuan Polisi Pamong Praja Provinsi Kalimantan Tengah (Disertasi, Universitas Terbuka).

Wirawan, D. (2014). Kepemimpinan: Teori, psikologi, perilaku organisasi, aplikasi dan penelitian. Jakarta PT. Rajagrafindo Persada. 